\title{
Design modularity: identification of benefits and difficulties through a bibliographical analysis in the perspective of automotive assemblers and suppliers
}

\author{
Flávio Issao Kubota, Leila Amaral Gontijo, Paulo Augusto Cauchick Miguel \\ Universidade Federal de Santa Catarina \\ e-mails: flavioissao.kubot@@gmail.com; leila@deps.ufsc.br; cauchick@deps.ufsc.br
}

\begin{abstract}
Modularity is a powerful concept applied in various industrial sectors. It assists designers and engineers in the development of products that have potential to comply with different markets. In this sense, this paper aims to analyze the literature on modularity focused on design modularity within the automotive industry. This sector has been increasingly applying the concept of modularity. It is a theoretical study that considered articles published in the past five years (since 2007) with regard to the issue "design modularity in the automotive industry". Publications were retrieved from peer-reviewed journals at major databases. The search identified 123 articles, from which 45 were suitable for content analysis. Results show that most recent publications cited as major benefits the customization, increased flexibility and product variety, and cost and time vehicle development reduction. The main difficulties are related to increased suppliers dependence (by vehicle assemblers) as well as innovation constraints by suppliers. Other aspects of the publications associated to the research approaches employed in the publications are also presented. Conclusively, benefits of modularity in design have been more exposed in the literature compared to the difficulties in the context of the automotive sector. It is observed that Original Equipment Manufacturers have more benefits than suppliers do, as the latter have more difficulties to adapt their organizational and productive processes towards design modularity. Finally, it is expected that the present work contributes to a broad theoretical framework concerning the benefits and difficulties of design modularity in the auto industry.
\end{abstract}

Keywords: modularity, modular design, automotive industry, literature analysis.

\section{Introduction}

Differentiated and innovative products have been increasingly desired and demanded by customers, who have become more discerning in their purchasing decisions. In areas where competitiveness is more intense, a creation of a differentiated product provides possibilities to the companies to be in the market.

One of the strategies that helps to improve products and processes is modularity, which aims to (BALDWIN; CLARK, 2004; CARNEVALLI; VARANDAS JÚNIOR; CAUCHICK MIGUEL, 2011): facilitate the management of complex products and processes through the division into simpler modules; enable parallel production activities, since modules can be manufactured simultaneously and; adapt production to future uncertainties, because the final product might be modified by adjustment of a single module or component, requiring a lower cost than redo the whole product (CORRÊA; KUBOTA; CAUCHICK MIGUEL, 2012). The concept of modularity is present in a variety of industries such as electronic, computing as well as the automotive sector. Those industrial sectors apply the modular strategy in their products and processes (ARNHEITER; HARREN, 2006; SALERNO et al., 2009). Moreover, it is clear that with the automotive sector growth and a consequent increase in vehicles' production and consumption in Brazil and worldwide, there has been a high increase in competition among automobile organisations.

In this context, series of decisions need to be taken into consideration to apply modularity in vehicle design, which demonstrate the complexity of this strategy (ASAN; POLAT; SERDAR, 2004). Like other strategies and methods, decisions about the design modularity degree and the choice of production processes significantly affect project development costs of cars. In this sense, this study conducts a review and a preliminary organization of the literature regarding the benefits and difficulties of design modularity in the automotive industry. One of its purposes is to offer a broad overview of this strategy for vehicle development. This work is part of a major research project on modularity, which previous results were published earlier (CAUCHICK MIGUEL, 2004, 2005; CAUCHICK 
MIGUEL; CABRAL NETTO; MARIOKA, 2009; CAUCHICK MIGUEL; HSUAN, 2010; CARNEVALLI; VARANDAS JÚNIOR; CAUCHICK MIGUEL, 2011; RODRIGUES; CARNEVALLI; CAUCHICK MIGUEL, 2009, 2012; CORRÊA; KUBOTA; CAUCHICK MIGUEL, 2012).

To fulfill this objective the paper is structured as follows. After this introduction, section 2 presents a theoretical framework about modularity concepts with the emphasis on design modularity. Section 3 describes the research methods followed by the presentation and discussion of the results in section 4. Finally, section 5 draws the conclusions and suggests issues for future research.

\section{Modularity concepts}

During the 1960s, modularity emerged in the computer industry, generating competitive advantage and demonstrating significant importance in the product development process (ARNHEITER; HARREN, 2006). The modular strategy consists in decomposing complex products in subsystems that are complete functional units, which can be designed and manufactured independently (which enables the construction of different products through subsystems combination), but with an integrated operation (BALDWIN; CLARK, 1997; PERSSON, 2006).

Morris and Donnelly (2006) distinguish two types of modularity: design - or product - and production. The authors firstly define modularity in design, which is focused on the boundaries among subsystems integrated components within design features and tasks. In addition, Graziadio (2004) states that modularity in design aims at reducing lead-time by doing different activities simultaneously. She adds that the adoption of this kind of modularity provides modules designed by specialized suppliers in a given category, which contributes to technological improvements.

Modular production enhances the final assembly of the product, allowing the occurrence of variability without increasing costs (SILVA; CAUCHICK MIGUEL, 2006). Stäblein, Holweg and Miemczyk (2011) complement this argument by saying that sharing modules and combine them in different versions expand product variety. The modularity in design is detailed next since is the focus of this paper.

\subsection{Design modularity}

Design modularity may be the most important factor to determine the product architecture configuration (ULRICH; EPPINGER, 2000). Mikkola and Gassmann (2003) corroborate this argument by citing that products with a high level of modularity allow high product variants by mixing and matching the product modules, while products with low modularity allow optimization of components for a particular product. Modularity helps in the development of products that have the possibility of meeting different markets (CARDOSO; KISTMANN, 2008). It is a concept used since the beginning of the century, however its use in design is a current trend not only in technology, but also in the industry in general (SILVA; CAUCHICK MIGUEL, 2006). Moreover, product modularity has been targeted as a way to accelerate new product development and reduce costs in this process (JACOBS et al., 2011).

Concerning product/design modularity, Morris, Donnelly and Donnelly (2004) state that it is focused on the boundaries among integrated components subsystems within design features and tasks, which should be interdependent modules (CAUCHICK MIGUEL, 2004). Graziadio (2004) and Cauchick Miguel, Cabral Netto and Marioka (2009) add that such modularity aims to reduce manufacturing time by performing different activities simultaneously and providing modules with the help of specialized suppliers, which theoretically contributes to technological improvements. Figure 1 illustrates one example of design modularity application, comparing modular architecture with an integral architecture of a vehicle.

\section{Research methods}

This study developed a preliminary literature analysis about the benefits and difficulties of adopting modularity in design within the context of the automotive industry. It is a theoretical-conceptual study as established in the literature (FILIPPINI, 1997; BERTO; NAKANO, 2000). To reach the study's objective, publications of interest were retrieved through a search in the following databases: Scopus, ISI Web of Knowledge, Emerald, SciELO, Science Direct. Some articles published in the International Journal of Automotive Technology and Management, which has restricted access and they are not available at CAPES journals portal (Coordenação de Aperfeiçoamento de Pessoal de Nível Superior - a Brazilian government agency for research support). It is important to mention that some articles had no free access and, therefore, they were not considered in the paper portfolio. This is one of the study limitations. To assist in recording and organizing the articles, the EndNote ${ }^{\circledR}$ X5 software was used. The following key expressions were used

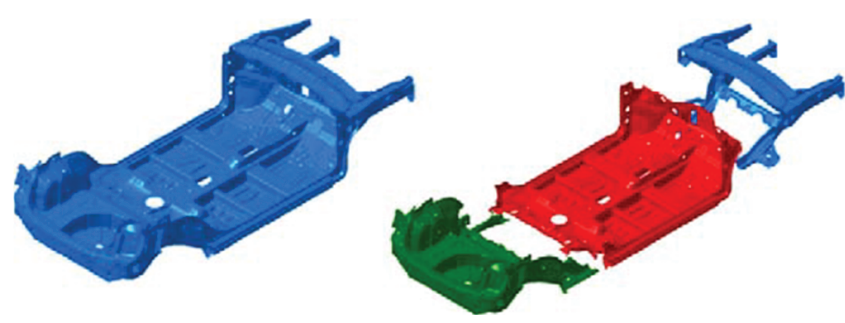

Figure 1. Inferior structure of a general vehicle - integral: left hand side and modular: right hand side (PARALIKAS et al., 2011). 
to search the databases: "modularity", "modularisation" (and its variation, e.g. "modularization"), "modular", "modular design", "modular product" in combination with the terms "automotive industry" and "auto industry".

The period between 2007 and 2012 was considered, since one of the objectives is a literature update on the subject verifying recent trends and characteristics of the related practices of design modularity, focused in the automotive industry. To organize the article portfolio, papers were classified in two groups: "conceptual research" and "empirical research". Conceptual studies were sub classified into "theoretical-conceptual", "literature review", "simulation" or "theoretical modeling". Empirical investigations were stated as "survey", "case studies" - single or multiple according to Yin (2005), "action research" or "experiment".

The nature of the data was also analyzed ("qualitative" or "quantitative"). The modularity typology focused was modularity in design/product. Production/process modularity and modularity in use will be investigated and analyzed in the future. Finally, data were also recorded in a Microsoft Excel ${ }^{\circledR}$ spreadsheet in order to build graphs and tables. Essentially, all paper contents (methods, theory or empirical results, and conclusions) of the papers were analyzed. The more related benefits and difficulties adopting design modularity in the automotive industry were identified, from both perspectives (automakers and suppliers). Finally, an analysis of the all features found in the papers was conducted and presented next.

\section{Results and discussion}

One hundred and twenty three articles were retrieved, from which 45 were considered after a content analysis. For example, articles addressing modularity in software, electrical equipment or in an organizational perspective were discarded because they are out of the research scope. The article portfolio encompassed papers that developed design modularity in functional or physical perspective (in this specific case, in automotive vehicles). Figure 2 illustrates the number of papers published by year. As can be seen the highest amount of publications (27\%) occurred in 2011.

Most articles employed have qualitative approach (93\%) and are empirical (76\%), i.e. have empirical applications in order to investigate how design modularity principles are used. Empirical studies are distributed as shown in Figure 3. As can be seen in the figure, most articles adopted it is highlighted case-based research as the methodological approach. The reasons for that were not identified.

A small portion of the article portfolio considered is theoretical papers $(24 \%)$. Within this group, there are more theoretical modeling studies (see Figure 4). Modularity was a new subject in the early 2000's, as reported by Salerno et al. (2009). After that, conceptual works were

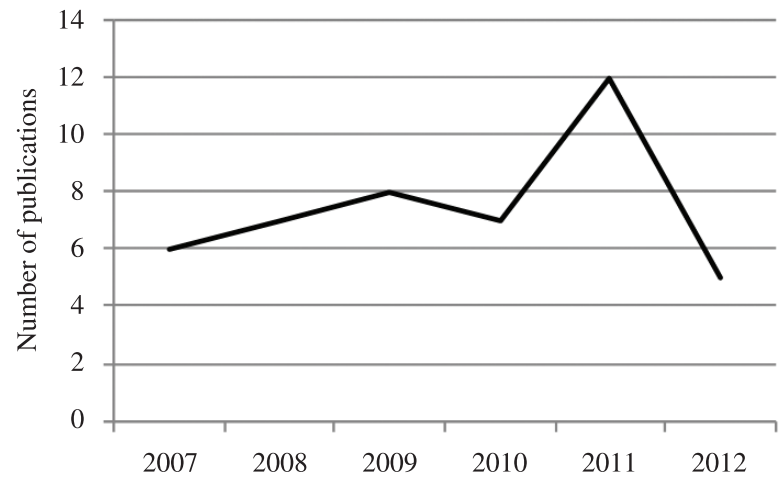

Figure 2. Publications per year of design modularity in the automotive industry.

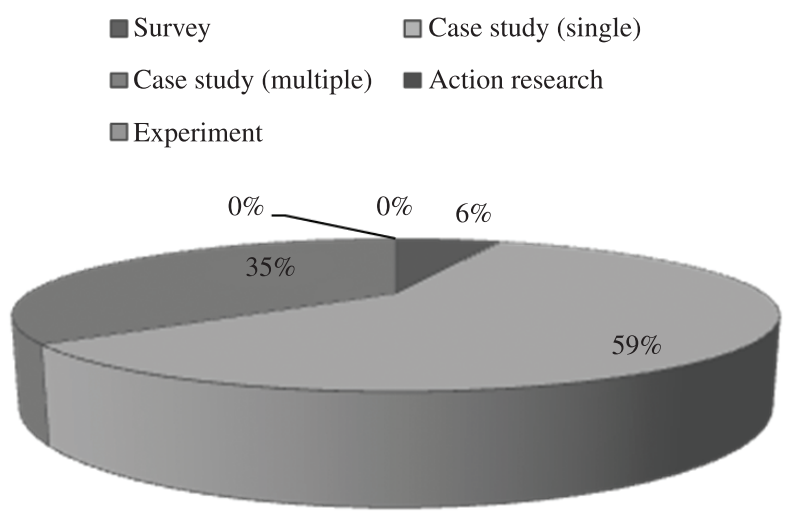

Figure 3. Empirical articles distribution according to their research methods.

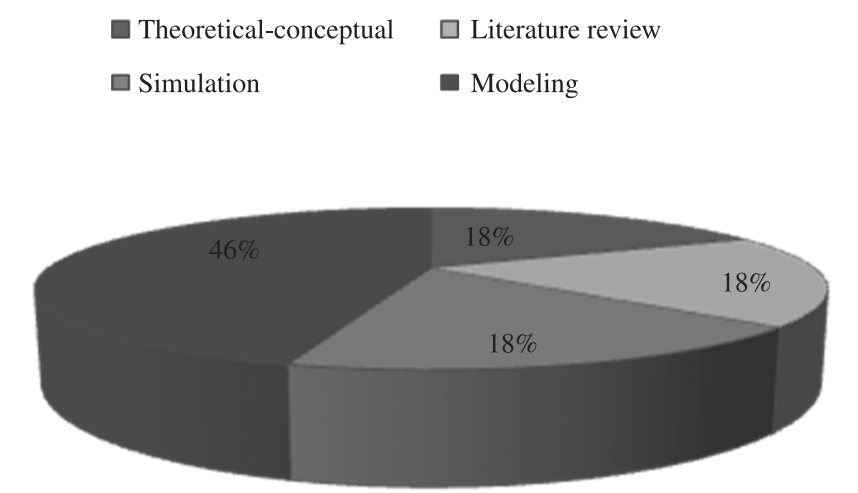

Figure 4. Conceptual articles distribution according to their research method.

more prominent as reported by Carnevalli, Varandas Júnior and Cauchick Miguel (2011) and Carnevalli and Cauchick Miguel (2009).

The 45 papers were published in 26 different journals, showing a wide range of periodicals publishing in this subject. The most prominent journals were: International 
Journal of Operations \& Production Management (4 papers), Produção (3 papers) and IEEE Transactions on Engineering Management (3 papers).

It was noted that the majority of Western publications focuses on production modularity instead of design modularity and the reverse occurs in the East, corroborating Carnevalli, Varandas Júnior and Cauchick Miguel (2011). After analyzing all papers, most cited benefits, difficulties, and recommendations when adopting modularity in design were identified. These findings are presented in the following sections.

\subsection{Benefits of design modularity in the auto industry}

Firstly, the identified benefits for automakers are:

- Reduction of product specifications and tasks complexity (POLITZE; DIERSSEN; WEGENER, 2012; CHRISTENSEN, 2011; BONJOUR; MICAELLI, 2010; CAUCHICK MIGUEL; CABRAL NETTO; MARIOKA, 2009) through the partition of them along developed product components (modules). This simplifies and facilitates the comprehension about product specifications;

- Higher customization possibility, flexibility, variety and adjusting product and components use according to consumer needs and/or desires (CARVALHO et al., 2012; PARALIKAS et al., 2011; RAY; RAY, 2011; CHRISTENSEN, 2011; CAUCHICK MIGUEL; HSUAN, 2010; WANG; KIMBLE, 2010; PANDREMENOS et al., 2009; CAUCHICK MIGUEL; CABRAL NETTO; MARIOKA, 2009; CARDOSO; KISTMANN, 2008; MACHADO; MORAES, 2008; ORSATO; WELLS, 2007; JACOBS; VICKERY; DROGE, 2007). The authors state that modularity enables to increase customization and provides greater product variety to consumers and customers;

- Reduction in product development time (ZIRPOLI; BECKER, 2011a, b; CARNEVALLI; VARANDAS JÚNIOR; CAUCHICK MIGUEL, 2011; OH; RHEE, 2010; CARNEVALLI; CAUCHICK MIGUEL, 2009; JACOBS; VICKERY; DROGE, 2007). Although studies do not quantify how much is time reduction, the literature reports successful cases and suggests that adopting design modularity enables a faster development, since the manufacturing of components can be done simultaneously;

- Product development costs and resources reduction and quality increase (ZIRPOLI; BECKER, 2011b; RAY; RAY, 2011; MAHMOUD-JOUINI; LENFLE, 2010; OH; RHEE, 2010; SANTOS; FORCELLINI, 2009; JACOBS; VICKERY; DROGE, 2007; DORAN et al., 2007). However, Carnevalli,
Varandas Júnior and Cauchick Miguel (2011) report that the required resources to develop the project have not lead necessarily to a large costs reduction because these costs are included in the values charged by the suppliers responsible for each module. Because this is a tangible benefit, there is an opportunity to quantify this reduction through quantitative economic models, for example.

The following benefits were identified for suppliers:

- Suppliers become more specialized in manufacturing components and parts (ZIRPOLI; BECKER, 2011b; MONDRAGON et al., 2009): with the modules division, suppliers have the opportunity of specializing in components that they are responsible. In fact, automotive industry suppliers are becoming specialists (MONDRAGON et al., 2009). Besides facilitating the division of labor, this can enable innovation and competitive advantage not only to suppliers but also to automakers, i.e. there is a mutual benefit;

- There are more independent and influent suppliers in the product development, since its conception (RODRIGUES; CARNEVALLI; CAUCHICK MIGUEL, 2012; ZIRPOLI; BECKER, $2011 \mathrm{a}, \mathrm{b}$; CERRA; MAIA; ALVES FILHO, 2011; SALERNO et al., 2009; RODRIGUES; CARNEVALLI; CAUCHICK MIGUEL, 2009; SACOMANO NETO; TRUZZI, 2009; MELLO; MARX, 2007a, b; ORSATO; WELLS, 2007). In addition, there is higher participation in modular design(RODRIGUES; CARNEVALLI; CAUCHICK MIGUEL, 2012; PRIETO; CAUCHICK MIGUEL, 2011; CERRA; MAIA; ALVES FILHO, 2011). When partitioning the product in different modules, suppliers have an increased degree of autonomy in developing products. It is important to point out that, in general, automakers still have control of all design specifications;

- Suppliers in a modular maturity degree have more potential in adding value to automakers and their business through constant competitive advantages generation, contribution and commitment to product "customization" (PRIETO; CAUCHICK MIGUEL, 2011). This can also enable long-term contracts and improving and strengthening the relationship between OEMs (Original Equipment Manufacturers) and suppliers. In addition, there is a possibility of higher information sharing and learning with the automaker (ZIRPOLI; BECKER, 2011b).

\subsection{Difficulties in adopting design modularity}

The main difficulties adopting design modularity in the automotive industry were also raised. To automakers the difficulties are: 
- Excessive component outsourcing (ZIRPOLI; BECKER, 2011a, b). Transferring responsibilities to suppliers brought issues in developing new products since there was a control loss on product specifications by OEMs (ZIRPOLI; BECKER, 2011a, b). Corroborating this argument, Carnevalli, Varandas Júnior and Cauchick Miguel (2011) reported module knowledge migration to suppliers, i.e. they began to take over key decisions in new product development because they became the main responsible for modules;

- Increased dependence on suppliers (RODRIGUES; CARNEVALLI; CAUCHICK MIGUEL, 2012; ZIRPOLI; BECKER, 2011b; CARNEVALLI; VARANDAS JÚNIOR; CAUCHICK MIGUEL, 2011), which can cause difficulties in productive and organizational processes according to the relationship between automaker and suppliers. Furthermore, many defined specifications during pre-product development will only be observed and tested after components assembly, which can generate high costs (even recalls depending on the issue) in case of noncompliance and/or inconsistency in full assembled product (ZIRPOLI; BECKER, 2011b);

- OEMs engineers might stagnate or even lose their knowledge during the components development, as suppliers become experts and deepens to generate improvements in them (RODRIGUES; CARNEVALLI; CAUCHICK MIGUEL, 2012; ZIRPOLI; BECKER, 2011a, b; PANDREMENOS et al., 2009). In a case study in a European automaker, Zirpoli and Becker (2011a) reported that the company had lost the competence of design some product components (panels, suspension and safety system). This is an example that demonstrates such difficulty;

- Product modularity is not suitable to solve performance issues in product (ZIRPOLI; BECKER, $2011 \mathrm{a}, \mathrm{b})$. The fact that the product is developed by modules contributes for the responsibility division in components assembly. However, ensuring effective assembly does not imply necessarily that the product as a whole will have the same effectiveness (ZIRPOLI; BECKER, 2011b). This occurs because modules integration influences one another. Thus, it emphasizes the need to identify the product performance tradeoffs, as reported in literature (e.g. ZIRPOLI; BECKER, 2011a);

- Complete vehicle redesign is necessary to fully explore modularity benefits, which takes time and additional product development costs (PANDREMENOS et al., 2009). An example of this difficulty is reported in Rodrigues, Carnevalli and Cauchick Miguel (2009), where a new truck needed a complete new cabin, engine and suspension to enable the project.

The following difficulties were identified for suppliers:

- Larger needs and efforts to adequate their (productive and organizational) processes to adaptation towards design modularity (CARNEVALLI; VARANDAS JÚNIOR; CAUCHICK MIGUEL, 2011). In general, automakers have more adequacy conditions to modularity actions, being suppliers the ones that need more efforts to adapt;

- Suppliers may also have a dependency relationship with automakers as they can have full control of projects (CERRA; MAIA; ALVES FILHO, 2011; MELLO; MARX, 2007a, b) and define the involvement degree of suppliers in design (SALERNO et al., 2009). This can cause restrictions and limitations to suppliers during modules development, which can difficult search for innovation in components - from suppliers;

- Excessive autonomy due to specialization can bring difficulties in the relationship with the OEM, since it does not have much interest in implementing technologies which they do not fully understand (MONDRAGON et al., 2009). Again, suppliers have limitations about to propose and develop innovations beyond incremental if automakers do not understand clearly ideas offered by suppliers.

\subsection{Literature recommendations regarding design modularity adoption}

From the literature analysis, it was possible to observe some recommendations in the literature with regard to the adoption of design modularity in the automotive industry. Modular products manufacturers may develop ways to strengthen communications among modules development teams (LAU; YAM; TANG, 2011; PAN et al., 2007). Thus, the responsibility and transfer definition are improved as well as the relationship between OEMs and suppliers. Furthermore, it is necessary to define design activities clearly to separate which will be automaker and supplier responsibility (ZIRPOLI; BECKER, 2011b). Moreover, due to increased product flexibility, additional efforts are needed to coordinate and manage modular components development (MIKKOLA, 2007). Another important feature in the product development concerns suppliers' participation intensity. In locally conducted new product development projects, it was observed most influent suppliers during vehicle development in comparison to cars developed at the headquarters located abroad (SALERNO et al., 2009).

The connection between division of labor ("who does what?") and knowledge ("who knows what?") cannot simply be managed based on modular product architecture 
(BRUSONI, 2005), i.e. it is a more complex activity. In addition, the management of each system individually does not imply that an effective vehicle integrated management will occur (ZIRPOLI; BECKER, 2011a). Regarding production systems aimed at enabling design modularity, they need to have flexibility to produce all variants required quickly (PARALIKAS et al., 2011). Aiming at achieving a higher customers satisfaction at a lower cost and to do it effectively, it is necessary a good tolerance management in place (PANDREMENOS et al., 2009) to provide standardized components and avoid excessive clearances and interferences, assembly inconsistency, etc., during product variants production. Regarding the impacts of design modularity in the supply chain, as in Lau, Yam and Tang (2007), it was not possible to find consensus in the literature about those effects.

Finally, it is important to seek innovation in modules that have higher perceived value according to customers and reuse modules that do not add value to the product (ROBERTSON; ULRICH, 1998). This can generate competitive advantage to OEMs and suppliers, because organizations will be strategically focused on their customers. Additionally, considering an operational viewpoint, reusing modules would minimize operational costs of manufactured components. However, it is important to point out that supply innovative proposals need to be understood by automakers. Otherwise, the actions might not become viable and attractive precisely for this reason (MONDRAGON et al., 2009). Having presented the results, the next section presents the conclusions of this study.

\section{Conclusions}

This study aimed to conduct a preliminary literature analysis on design modularity in automotive industry. Although this is the first part of an ongoing study, it was possible to identify a number of benefits and difficulties recently reported in the literature. Firstly, in the design point of view, modularity brings contributions mainly regarding to the possibility of fulfill market needs and expectations in a more agile and flexible manner. Moreover, modular product conception is facilitated through component sharing, simplifying the product and turning it less complex. This implies in contributions to product architecture knowledge.

Concerning research methodology in the publications, empirical investigations have gained more attention than conceptual studies. This means that the most recent interest is to investigate how modularity has been adopted within the industry context by conducting empirical studies. Nevertheless, single case studies are predominant, despite of their limitation due to their external validity. Positively, multiple case studies are also present in the publications. With regard to conceptual papers, most interest is to establish a framework for future empirical investigations.
In the automotive sector, benefits have been more exposed than difficulties. It is reported that OEMs have more benefits than suppliers, since the latter have more difficulties to adapt their organizational and productive processes towards design modularity. In general, automakers have benefits in product architecture and development, increasing flexibility and variety offering to customers, more intense relationship with suppliers (which also have benefits in this sense), and product development time and costs reduction (although there is no quantification in the literature of how much time is reduced). Suppliers can specialize and may contribute with modules innovation, establish long-term contracts with OEMs, have more autonomy in components development as well as and higher influence in developing product architecture since their pre-conception.

OEMs main difficulties concern loss of control regarding product specifications, which turns to be suppliers responsibility, bringing consequently larger suppliers dependence and more coordination demands to manage manufacturing activities. Suppliers have issues about increased responsibility in product development and innovation restrictions during the product development process, since automakers have control of most activities.

Recommendations for design modularity adoption in the auto industry involve aspects such as clearly define design and product activities, methods and tools to increase communication among teams (OEM and suppliers), seek innovation in the most relevant (according to customers) modules, and organize the production system to generate the variants needed.

It is expected that this study brings theoretical contributions with regard to benefits, difficulties and recommendations observed in literature when adopting design modularity in the automotive sector. Future research involves to develop a broader theoretical framework, considering the main influent aspects on vehicle development as well as to analyze empirically implications about the recommended actions in OEMs that adopt modularity. In addition, it is intended to enlarge the study to a more robust theoretical context, by considering papers on modularity in production and modularity in use in the automotive industry as well as the relationships among the various typologies of modularity.

\section{Acknowledgments}

The authors thank CAPES (Coordenação de Aperfeiçoamento de Pessoal de Nivel Superior, a Brazilian government agency for research support) as well as CNPq (Brazilian National Council for Scientific Development) for providing the grants and financial support. The authors also appreciate the assistance of some researcher students who more recently work in this project, namely: Eduardo Mathias, José Antonio Carnevalli, and Leonardo de Aguiar Corrêa as well as others who previously participated in this work. 


\section{References}

ARNHEITER, E. D.; HARREN, H. Quality management in a modular world. The TQM Magazine, v. 18, n. 1, p. 8796, 2006. http://dx.doi.org/10.1108/09544780610637712

ASAN, U.; POLAT, S.; SERDAR, S. An integrated method for designing modular products. Journal of Manufacturing Technology Management, v. 15, n. 1, p. 29-49, 2004. http:// dx.doi.org/10.1108/09576060410512257

BALDWIN, C. Y.; CLARK, K. B. Managing in an Age of Modularity. Harvard Business Review, v. 75, n. 5, p. 8493, 1997.

BALDWIN, C. Y.; CLARK, K. B. Modularity in the Design of Complex Engineering Systems. 2004. Disponível em: <http://www.people.hbs.edu/cbaldwin/DR2/ BaldwinClarkCES.pdf>. Acesso em: 10 jan. 2013.

BERTO, R. M. V. S.; NAKANO, D. N. A produção científica nos anais do Encontro Nacional de Engenharia de Produção: um levantamento de métodos e tipos de pesquisa. Produção, v. 9, n. 2, p. 65-76, 2000. (in Portuguese). http://dx.doi. org/10.1590/S0103-65131999000200005

BONJOUR, E.; MICAELLI, J. P. Design Core Competence Diagnosis: A Case From the Automotive Industry. IEEE Transactions on Engineering Management, v. 57, n. 2, p. 323-337, 2010. http://dx.doi.org/10.1109/ TEM.2009.2036838

BRUSONI, S. The limits to specialization: problem-solving and coordination in modular networks. Organization Studies, v. 26, n. 12, p. 1885-1907, 2005. http://dx.doi. org/10.1177/0170840605059161

CARDOSO, M. A.; KISTMANN, V. B. Modularização e design na indústria automotiva: o caso do modelo Fox da Volkswagen do Brasil. Revista Produção Online, v. 8, n. 4, 2008. (in Portuguese).

CARneVAlli, J. A.; CAUCHICK Miguel, P. A. Classificação e análise inicial da literatura sobre a utilização da modularidade no setor automotivo. In: CONGRESSO BRASILEIRO DE GESTÃO E DESENVOLVIMENTO DE PRODUTO, 10., 2009. Anais eletrônicos... São José dos Campos, 2009. CD-ROM. (in Portuguese).

CARNEVALLI, J. A.; VARANDAS JÚNIOR, A.; CAUCHICK MIGUEL, P. A. Uma Investigação sobre os Benefícios e Dificuldades na Adoção da Modularidade em uma Montadora de Automóveis. Produto \& Produção, v. 12, n. 1, p. 60-90, 2011. (in Portuguese).

CARVALHO, I. et al. Reducing fuel consumption through modular vehicle architectures. Applied Energy, v. 93, p. 556563, 2012. http://dx.doi.org/10.1016/j.apenergy.2011.12.004

CAUCHICK MIGUEL, P. A. Perspectivas e implicações da modularidade do desenvolvimento de produto - estudo bibliográfico inicial. In: SIMPÓSIO DE ENGENHARIA DE PRODUÇÃO, 11., 2004, Bauru. Anais eletrônicos... Bauru, 2004. Disponível em: <http://www.simpep.feb. unesp.br/anais_simpep_aux.php?e=11>. Acesso em: 20 mar. 2012. (in Portuguese).

CAUCHICK MIGUEL, P. A. Modularity in product development: a literature review towards a research agenda. Product: Management \& Development, v. 3, n. 2, p. 165174, 2005.

CAUCHICK MIGUEL, P. A.; CABRAL NETTO, O. V.; MARIOKA, S. N. Uma investigação sobre a adoção da modularidade no projeto de novos produtos e na produção em uma montadora automotiva. Produto \& Produção, v. 10, n. 3, p. 7-18, 2009. (in Portuguese).

CAUCHICK MIGUEL, P. A.; HSUAN, J. An exploratory investigation on modularity adoption in design and production through a case-based research in a Brazilian automaker. Product: Management \& Development, v. 8, n. 2, p. 173-181, 2010.

CERRA, A. L.; MAIA, J. L.; ALVES FILHO, A. G. Envolvimento de fornecedores em atividades de Desenvolvimento de Produtos de montadoras de motores para automóveis. GEPROS - Gestão da Produção, Operações e Sistemas, v. 6, n. 1, p. 25-40, 2011. (in Portuguese).

CHRISTENSEN, T. B. Modularised eco-innovation in the auto industry. Journal of Cleaner Production, v. 19, n. 2-3, p. 212-220, 2011. http://dx.doi.org/10.1016/j. jclepro.2010.09.015

CORRÊA, L. A.; KUBOTA, F. I.; CAUCHICK MIGUEL, P. A. Towards a contribution to modularity concepts and principal domains. Product: Management \& Development, v. 10, n. 2, p. 1-12, 2012.

DORAN, D. et al. Supply chain modularisation: Cases from the French automobile industry. International Journal of Production Economics, v. 106, n. 1, p. 2-11, 2007. http:// dx.doi.org/10.1016/j.ijpe.2006.04.006

FILIPPINI, R. Operations management research: some reflections on evolution, models and empirical studies in OM. International Journal of Operations and Production Management, v. 17, n. 7, p. 655-670, 1997. http://dx.doi. org/10.1108/01443579710175583

GRAZIADIO, T. Estudo Comparativo entre os Fornecedores de Componentes Automotivos de Plantas Convencionais e Modulares. 2004. Tese (Doutorado em Engenharia de Produção)-Universidade de São Paulo, São Paulo, 2004. (in Portuguese).

JACOBS, M.; VICKERY, S.K.; DROGE, C. The effects of product modularity on competitive performance: Do integration strategies mediate the relationship? International Journal of Operations \& Production 
Management, v. 27, n. 10, p. 1046-1068, 2007. http:// dx.doi.org/10.1108/01443570710820620

JACOBS, M. et al. Product and Process Modularity's Effects on Manufacturing Agility and Firm Growth Performance. Journal of Production and Innovation Management, v. 28 , n. 1, p. 123-137, 2011. http://dx.doi.org/10.1111/ j.1540-5885.2010.00785.x

LAU, A. K. W.; YAM, R. C. M.; TANG, E. The impacts of product modularity on competitive capabilities and performance: an empirical study. International Journal of Production Economics, v. 105, n. 1, p. 1-20, 2007. http:// dx.doi.org/10.1016/j.ijpe.2006.02.002

LAU, A. K. W.; YAM, R. C. M.; TANG, E. The Impact of Product Modularity on New Product Performance: Mediation by Product Innovativeness. Journal of Production \& Innovation Management, v. 28, n. 2, p. 270-284, 2011. http://dx.doi.org/10.1111/j.1540-5885.2011.00796.x

MACHADO, A. G. C.; MORAES, W. F. A. Estratégias de customização em massa implementadas por empresas brasileiras. Produção, v. 18, n. 1, p. 170-183, 2008. (in Portuguese). http://dx.doi.org/10.1590/S010365132008000100013

MAHMOUD-JOUINI, S. B.; LENFLE, S. Platform re-use lessons from the automotive industry. International Journal of Operations \& Production Management, v. 30, n. 1, p. 98124, 2010. http://dx.doi.org/10.1108/01443571011012398

MELLO, A.; MARX, R. Conhecimento de Arquitetura de Produto como Elemento Chave para a Manutenção da Capacidade Inovadora de uma Empresa - O caso da Indústria Automotiva. Revista Gestão Industrial, v. 3, n. 2, p. 74-88, 2007a. (in Portuguese). http://dx.doi.org/10.3895/ S1808-04482007000200006

MELLO, A.; MARX, R. Innovative capacity maintenance by automakers in a product development outsourcing scenario: the case of VW in Brazil. International Journal of Automotive Technology and Management, v. 7, n. 2-3, p. 200-215, 2007b. http://dx.doi.org/10.1504/ IJATM.2007.014975

MIKKOLA, J. H. Management of Product Architecture Modularity for Mass Customization: Modeling and Theoretical Considerations. Engineering, v. 54, n. 1, p. 5769, 2007.

MIKKOLA, J. H.; GASSMANN, O. Managing modularity of product architectures: Toward an integrated theory. IEEE Transactions on Engineering Management, v. 50, n. 2, p. 204-218, 2003. http://dx.doi.org/10.1109/ TEM.2003.810826

MONDRAGON, C. C. et al. Managing technology for highly complex critical modular systems: The case of automotive by-wire systems. International Journal of Production
Economics, v. 118, n. 2, p. 473-485, 2009. http://dx.doi. org/10.1016/j.ijpe.2008.12.015

MORRIS, D.; DONNELLY, T. Are there market limits to modularisation? International Journal of Automotive Technology and Management, v. 6, n. 3, p. 262-275, 2006. http://dx.doi.org/10.1504/IJATM.2006.012120

MORRIS, D.; DONNELLY, T.; DONNELLY, T. Insights from Industry: Supplier Parks in the Automotive Industry. Supply Chain Management: An International Journal, v. 9, n. 2, p. 129-133, 2004. http://dx.doi. org/10.1108/13598540410527024

$\mathrm{OH}$, J.; RHEE, S. K. Influences of supplier capabilities and collaboration in new car development on competitive advantage of carmakers. Management Decision, v. 48, n. 5, p. 756-774, 2010.

ORSATO, R.; WELLS, P. Introduction - The Automobile Industry \& Sustainability. Journal of Cleaner Production, v. 15, n. 11-12, p. 989-993, 2007. http://dx.doi.org/10.1016/j. jclepro.2006.05.035

PAN, S. L. et al. The Dynamics of implementing and managing modularity of organizational routines during capability development: Insights from a process model. IEE Transactions on Engineering Management, v. 54 , n. 4, p. $800-813$, 2007. http://dx.doi.org/10.1109/ TEM.2007.906854

PANDREMENOS, J. et al. Modularity concepts for the automotive industry: A critical review. CIRP Journal of Manufacturing Science and Technology, v. 1, n. 3, p. 148152, 2009. http://dx.doi.org/10.1016/j.cirpj.2008.09.012

PARALIKAS, J. et al. Product modularity and assembly systems: An automotive case study. CIRP Annals - Manufacturing Technology, v. 60, n. 1, p. 165-168, 2011.

PERSSON, M. Effects of changing a module's interface: a case study in an automotive company. International Journal of Automotive Technology and Management, v. 6 , n. 3, p. 331-345, 2006. http://dx.doi.org/10.1504/ IJATM.2006.012124

POLITZE, D.; DIERSSEN, S.; WEGENER, K. Function module drivers for assessing the similarity between product functions. CIRP Journal of Manufacturing Science and Technology, v. 5, n. 1, p. 33-40, 2012. http://dx.doi. org/10.1016/j.cirpj.2011.11.001

PRIETO, E.; CAUCHICK MIGUEL, P. A. Adoção da estratégia modular por empresas do setor automotivo e as implicações relativas à transferência de atividades no desenvolvimento de produto: um estudo de casos múltiplos. Gestão \& Produção, v. 18, n. 2, p. 425-442, 2011. (in Portuguese). http://dx.doi.org/10.1590/S0104-530X2011000200015

RAY, S.; RAY, P. K. Product innovation for the people's car in an emerging economy. Technovation, v. 31, 
n. 5-6, p. 216-227, 2011. http://dx.doi.org/10.1016/j. technovation.2011.01.004

ROBERTSON, D.; ULRICH, K. Planning for product platforms. Sloan Management Review, v. 39, n. 4, p. 1931, 1998.

RODRIGUES, E. A.; CARNEVALLI, J. A.; CAUCHICK MIGUEL, P. A. Aplicação da modularidade no projeto e na produção: uma análise em uma montadora de caminhões e ônibus. GEPROS - Gestão da Produção, Operações e Sistemas, v. 4, n. 4, p. 79-92, 2009. (in Portuguese).

RODRIGUES, E. A.; CARNEVALLI, J. A.; CAUCHICK MIGUEL, P. A. Uma investigação sobre a relação entre o projeto do produto e produção em uma montadora automotiva e fornecedores de motores que adotam a modularidade. Produção, v. 22, n. 3, p. 367-379, 2012. (in Portuguese). http://dx.doi.org/10.1590/S0103-65132012005000019

SACOMANO NETO, M.; TRUZZI, O. Posicionamento estrutural e relacional em redes de empresas: uma análise do consórcio modular da indústria automobilística. Gestão \& Produção, v. 16, n. 4, p. 598-611, 2009. (in Portuguese). http://dx.doi.org/10.1590/S0104-530X2009000400009

SALERNO, M. S. et al. The importance of locally commanded design for the consolidation of local supply chain: the concept of design headquarters. International Journal of Manufacturing and Management, v. 16, n. 4, p. 361376, 2009. http://dx.doi.org/10.1504/IJMTM.2009.023753

SANTOS, A. C.; FORCELLINI, F. A. Effects of product decision-making process on the supply chain. Product: Management \& Development, v. 7, n. 1, p. 39-46, 2009.
SILVA, H. O. L.; CAUCHICK MIGUEL, P. A. Adoção da modularidade no desenvolvimento de produto - um estudo de caso em uma montadora de veículos. In: SIMPÓSIO DE ENGENHARIA DE PRODUÇÃO, 13., 2006, Bauru. Anais eletrônicos... Bauru, 2006. Disponível em: <http:// www.simpep.feb.unesp.br/anais_simpep.php?e=4>. Acesso em: 02 abr. 2012. (in Portuguese).

STÄBLEIN, T.; HOLWEG, M.; MIEMCZYK, J. Theoretical versus actual product variety: how much customisation do customers really demand? International Journal of Operations \& Production Management, v. 31, n. 3, p. 350370, 2011. http://dx.doi.org/10.1108/01443571111111955

ULRICH, K. T.; EPPINGER, S. D. Product design and development. 2nd ed. Boston: Irwin/McGraw-Hill, 2000.

WANG, H.; KIMBLE, C. Low-cost strategy through product architecture: lessons from China. Journal of Business Strategy, v. 31, n. 3, p. 12-20, 2010. http://dx.doi. org/10.1108/02756661011036664

YIN, R. K. Estudo de caso: planejamento e método. Porto Alegre: Bookman, 2005. (in Portuguese).

ZIRPOLI, F.; BECKER, M. C. What Happens When You Outsource Too Much? MIT Sloan Management Review, v. 52, n. 2, p. 58-65, 2011a.

ZIRPOLI, F.; BECKER, M. C. The limits of design and engineering outsourcing: performance integration and the unfulfilled promises of modularity. R\&D Management, v. 41, n. 1, p. 21-43, 2011b. http://dx.doi.org/10.1111/j.14679310.2010.00629.x 